Anna R. Muradova

Institute for Linguistic Studies

Moscow, Russia

\title{
BRETON LANNEG AND RUSSIAN ЛЯДА: ASPECTS OF LIMINALITY IN CELTIC AND SLAVIC FOLK TALES ${ }^{1}$
}

\section{Introduction}

Studying the language of Breton folklore, the scholar should probably resist any temptation to compare similar elements found in different traditions which had never been in close contact to it. In fact, in most cases one can only explain few common features exhibited in the folktales as various traces of archaic rituals, which was demonstrated some time ago by Claude Lévi-Strauss (1964; 1968), or one can study them as common structures of the folktale, as was indicated in Vladimir Propp's $(1968)^{2}$ seminal study. But in some cases linguistic data can be useful in relation to the comparative study of the folktales. Tentative etymological reconstruction can be quite facilitating not only in relation to finding parallels between the traditions in question, but also in relation to giving some plausible reconstructions of a general folklore narrative unit or a particular element of the tradition. The aim of my article is to provide an example of the way the etymology can facilitate the comparative study, reconstructing a folkloristic plot according to which a shepherd should keep his flocks safe on the wasteland.

\section{Breton folktale fozebik ha Merlin}

I would like to start with a Breton folktale fozebik ha Merlin recorded by Jef Philippe in 1980 from JeanLouis Rolland. Though the version of the tale itself is recent, it contains some archaic elements and the episode I will speak about relates to the plot of the hero's fight with the giants and with the dragon on the wasteland.

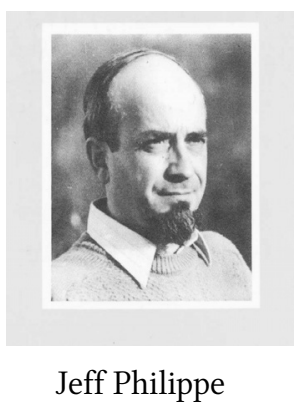

${ }^{1}$ Cf. also Alan Dundes's contribution to the subject (1962) as well as his useful introduction to the second edition of Propp's Morphology of the Folktale (1968: x-xvii) with accompanying bibliography.

2 See Afanasiev 2008; Propp 1968, 1984, 1989; Meletinski 1968, 1994, 1998; Neklyudov 1971, 2004 and other related works. 
The wasteland (Breton al lanneg, pl. lannoù, lanneier) is a liminal zone which the hero enters before he finds himself in a magic wood. In the Breton folktales, all the shepherds normally walk through the wasteland with their cattle, and then on into the wood where they are killed by the giants who dwell there. According to the fairy tale in question, it is Jozebik who is able to kill the giants and therefore becomes the master of their castle in the middle of the wood. There he finds beautiful clothes and magic horses. The wasteland is represented as some kind of a boundary zone which only Jozebic can enter. This is quite clear from the following description:

Met an deiz war-lerc'h da vintin, a-benn ma oa prest ar paotr-deñved da vont d'al lanneg, homañ a oa ken prest hag eñ da vont gant an deñved d'al lanneg. Pa 'mañ erruet eno e vanke dezhi e vije chomet ganti da c'hoari.

"O! 'laras ar paotr-deñved, 'me n'on ket deuet amañ da c'hoari ganeoc'h! Ha kit d'ar gệr, mar karit, pe chomit aze! Me a rank mont gant an deñved!"

Mont a reas war-lerc'h e zeñved ha leuskell anezhi eno da sellout endro ma kare (Philippe 1986: 51).

Next morning then Jozebik went with his sheep to the wasteland. The master's daughter (i.e. the king's daughter) followed him and his animals. They came to the wasteland and she asked him to play with her. "I'm not here to play with you", the shepherd answered, "Go home or stay here. I must follow the sheep".

He went away with the sheep and left her there.

For a number of days when the two meet, they keep on making the same conversation. It is obvious that for some reasons the girl cannot go with the hero through the wasteland even if she wants to follow him. But the reason for this has not been made explicit in the story. It is understandable that for the storyteller the meaning of this episode is not very clear and needs some additional explanation. Therefore, J.-L. Rolland goes on to add that the girl is afraid of the giants who live in the forest. But even when the giants are killed she doesn't dare to follow the shepherd who keeps visiting the wasteland without any difficulty. $C f$. two examples below:

(a) Pa 'mañ erruet e-kreiz al lanneg, ez eas buhan da voueta e gezeg, ha da gempenn anezho (Philippe 1986: 57).

Having said this, Jozebik went to follow his sheep.

When he was on the wasteland with his animals, he ran away to look after his horses and to feed them. 
(b) Met ar paotr a c'haloupas etrezek kreiz al lanneg war-lerc'h an deñved. Ha pa ne welas ket anezhi ken, ez eas da welout penaos e oa kont gante gezeg, ha da voueta anezho, kar n'eo ket traoù a vanke eno (Philippe 1986: 58).

The shepherd didn't want to listen to the girl and ran away with his sheep.

When he was far enough and the girl couldn't see him, he went to the forest to feed his horses because there was a lot of food for them.

This episode demonstrates that no one save for Jozebig who conquered the giants can enter the magic wood. However, while the tale goes on, it presents us with another motif: the hero must kill a dragon. And the conditions for crossing the wasteland in this instance are not the same as

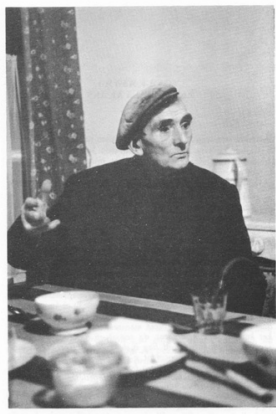

Jean-Louis Rolland those called upon previously. The king's daughter must be sacrificed to the dragon that lives in a cave at the rear of the wasteland. In the course of the story, the girl provides a following explanation as to why she was chosen:

"Rak er vro-mañ, ar roue en deus ur verc'h a-bep seizh vloaz da gas d'ar sarpant a zo en un toull en tu all d'al lanneg, $e$-kichenn ar c'hoad a zo du-se. Hag ez eus graet plouz berr etre ma div c'hoar ha me, ha me 'zo degouezhet da vont d'ar sarpant'" (Philippe 1986: 58). "Because in this country, the king must every seven years send one of his daughters to the dragon that lives at the rear of the wasteland not far from the forest nearby. And we threw lots, my two sisters and me and it was my turn to go to the dragon's hole."

So, the young girl must go to the dragon's "hole" and for this purpose she must cross the wasteland which she was not allowed to do before. But no one (and the storyteller tells this explicitly) can cross the boundary zone with her save for the hero who finally delivers her from the evil beast.

$\mathrm{Pa}$ 'mañ erruet (gant merc'h ar roue) e welas anezhi, he mouchouer ganti en he dorn, o hejal d'he zud a oa en tu all d'al lanneg, o sellout outi o vont d'ar sarpant, an drapoioù du ganto evit ober kañv dezhi (Philippe 1986: 59).

He (Jozebik) followed the king's daughter and soon he saw her. She was standing with her handkerchief saying good-bye to her parents, and they were standing on the opposite side of the wasteland holding black flags and watching her going to the dragon's hole. 
Paying great attention to the action, the storyteller skips through some minute details. But for us these details are very important because they show the archaic motif of the hero's struggle with the dragon and the connection of this motif to the notion of the boundary zone (the wasteland). The black flags are an obvious allusion to the funeral rite. And for the listeners it is clear that the procession on the border of the wasteland is a funeral one, as the girl must die. She behaves as if she is an already deceased person and by the virtue of her status she is allowed to cross over to the wasteland. It is likely that both the magic wood and the dragon's hole located behind the wasteland represent the Otherworld. And only the hero (who already succeeded in overthrowing the supernatural creatures) and the sacrificed person (represented as departed from the world of the living) can go there. For others the access to the boundary zone is forbidden. After the girl is saved by the hero and returned to her parents she has no access to the wasteland anymore, and therefore she cannot follow the shepherd.

Mont a reas (merc'h ar roue) gantañ adarre betek toull al lanneg, hag e reas bec'h dezhañ, da chom ganti. Met ar paotr-deñved ne chomas ket da selaou anezhi, met mont etrezek kreiz al lanneg ha da vouetaad e gezeg (Philippe 1986: 59).

The girl followed him once more to the place where the wasteland starts and began to annoy him asking to stay with her. But the shepherd didn't stay and listen to her; he went straight through the wasteland to give some food to his horses.

The connection of the wasteland and the motive of fighting a dragon is not a very common one in the Breton folktales. In fact, it is important to underline that the struggle with a dragon is an extremely rare plot in the Breton fairytales. If we compare this to the Russian tradition, the difference will be striking. Meanwhile, we can find some close parallels from other narratives.

In this vein let us turn our attention to other linguistic data which may help us in elucidating the role of wasteland in Breton folklore. The word lann, lanneg (plur. lannioù, lannoù, lanneier, lanneierou, lannoueier) used in the folktale fozebik ha Merlin obtains several meanings in Modern Breton, one of them being 'the wasteland'. But other meanings of the word lann can help us in reconstructing the concept and can provide us with a better understanding of the sacrifice episode and the hero's fight with the supernatural forces. 


\section{Breton toponymic evidence and the element lann-}

In order to understand the concept of the wasteland as a liminal zone it is necessary to employ the linguistic data. The element lann- is quite common in contemporary Breton place names.

Breton place-names beginning with element lann- can provide us with an idea what the lexeme actually meant in the early medieval age. Lann was used to denote either (a) a small monastery building where several monks used to live or (b) the territory near this building or (c) a hermitage with a chapel ( $c f$. contemporary place-names Landevennec, Langoat, Lannilis). In this regard, place-names beginning with lan- (or lam- as a result of $n+p>$ $m p ; n+b>m b$ assimilation, as in Lampaul, Lamballe) come from a word denoting either a Christian sacred building or a sacred territory. But at the same time, both in Old Breton and in the modern language, the word lann can mean a type of a wild landscape, more specifically, the land which is not cultivated for the agricultural purposes. To our mind, the two meanings (an ecclesiastical vs. the undomesticated one) are quite distinct from each other, but in the period of the sixth-seventh centuries $\mathrm{AD}$ when the foundation of the parishes was taking place in Lower Brittany they were very close.

The role of the churches located on the boundaries in Brittany, Wales and Ireland was carefully studied in the article "Boundary Association in Early Irish Society" by Pádraig Ó Riain. Some points need to be mentioned in this vein:

In Gaul, the frontiers between tribes... were belts of uncultivated land, the idea of frontier merging with that of wasteland or forest. Such borderlands came to serve as tribal assembly places or as meeting-places for trading transaction... The idea of sanctuary-location on tribal frontier is widely held among historians of Gaul... Cult-centers, which must have been accompanied by some form of permanent residence, lay frequently at or near territorial boundaries... We encounter the idea of a boundary merging with that of wasteland (Ó Riain 1972: 14, 16).

More precisely, in Early Ireland the idea of a church founded on a boundary zone is connected with the cattle pasture. According to Ó Riain (1972: 17), "the cow or other animal figures regularly in the choice of the spot on which to locate a church".

Ó Riain proposes that Irish, Welsh or Cornish parochial churches were seldom located in the centre of a parish. As for the Breton churches, he admits that 
This happens to be a regular feature of parochial organization in Brittany. Curiously however, this (location in the center - AM) only applies to churches in parishes designated by the loan-word Plouwhereas the churches designated by Lan- occupy an equally inaccessible position in respect to the parishes in which they are found, to that of the Irish, Welsh, and Cornish parochial churches... This peculiar feature of Celtic parochial organisation derives directly from the tendency to locate churches on the boundary territorial units... (Ó Riain 1972: 18-19).

I would like to stress the importance of the fact that there is an obvious difference between the names of the parishes beginning with Lannand the ones beginning with Plou- (borrowed from Lat. plebs) and Guic(Lat. vicus). What is the meaning of the prefix lann- and how the meaning of this lexeme in Old, Middle and Modern Breton can be connected to the concept of wasteland and that of liminality?

3. The meaning of lanneg in Modern Breton lexicography and its IE cognates

In Modern Breton, the word lann, lanneg has two meanings - 'the wasteland' and 'a sacred place' ('church', 'chapel'; 'lieu consacre du village', GBV). These meanings are present in other Celtic languages: $c f$. Corn. lan 'wasteland', Middle Welsh llan 'area', Modern Welsh llan 'church, parish, village, yard', Gaul. *landa 'wasteland', and Modern Frech lande, Ital. landa; Old Irish lann (land) 'land, ground house, building, church'. In Germanic languages, this word has only one meaning: 'land, ground' (Germ. land, Engl. land, cf. Old Prussian lindan 'valley').

The Old Church Slavonic cognate, "leda/led $/$ /ledo has a meaning closer to the Celtic one. Not only it is the wasteland, but the cognate lexemes both in Celtic and in Slavic derive from the IE stem *lendh- 'wasteland'. This stem obtains a connotation of the malicious sacred force.

While examining the connotations of lanneg, lann, we see that the word is translated into French in dictionaries (GVB; Gros 1989) not only with the employment of the word lande, but also as "anc. lande d'ermite, lieu consacré du village" (GVB). The OB. lann is also mentioned, translated like monasterium, curia, $c f$. Old Breton abbaye (GBV).

In phraseology of Modern Breton, the lann(eg) type of landscape is treated as a malicious one, as a 'bad, dangerous place'.

Lanneg $(f)$ lande (pl. lanneier, lanneierou) - Med, fedamdoulle, me a oa eet euz ar prad (et: eus ar park) d'al lanneg! Mais, nom d'un 
chien, j'etais allé du pré (et du champ) à la lande (j'avais quittè une bonne maison, une bonne situation, pour une mauvaise). - O, hell ! I went from a meadow to the wasteland (= I escaped a bad situation to get into a worse one!) (Gros 1989: 305).

Favereau provides a following translation to the phrase moned eus ar prad d'al lanneg 'to go from Charibda to Schylla' (GBV).

Not only in Breton, but in other IE languages the words that derive from this stem have a meaning of 'dangerous place'. Vladimir N. Toporov examined the Prussian cognate linden 'wasteland', and provided some examples from the Baltic languages, where the word means the land which was "not cultivated but which may still potentially be yet successfully cultivated in future; $c f$. the so-called Elliot's "The Waist Land"; because of the fact of its "abandonment" it was regarded as a force of the past, of the primordial chaos and was not included into the cultural context" (Toporov 1990: 263-266).

This interpretation is corroborated by Ó Riain's hypothesis on the character of wasteland in Early Ireland:

Their cultivation was obviously a secondary development: yet the whole tenor of the Irish evidence suggests that these same zones developed into the focal points of socio-religious activity (Ó Riain 1972: 26).

As far as the Russian language is concerned, the IE stem *lendh- finds its cognates in a dialectal Russian lexeme lyada (Russ. ляда). Vladimir Dal in his Dictionary of the Russian language provides several meanings of the word:

Ляда, ляда́, ляди́на, ж. зап. слав. лядо - пустошь, заросль, покинутая и заросшая лесом земля... вообще: низкая, мокрая, и плохая почва (Dal 1979: II, 286).

Lyáda, lyadá, lyadína, fem., West. Slav. - wasteland, brushwood, a deserted land covered with wood, generally, a low, wet and bad soil.

There is also an example provided by Dal which shows a connection of lyada with the concept of pasture: Скот в лядник ходит "The cattle go to lyadnik" (Dal 1979: II, 286). He also cites few parables in which the word is used to denote a grazing land:

Сухой Гаврилка вскочил в лядинку, разогнал всю скотинку Гребень (Dal 1979: II, 286).

A dry Gabriel hopped onto the wasteland and drove away all the cattle. Answer: a comb.

Стоят вилы, на вилах-то бочка, на бочке-то кочка, на кочке зевало, повыше ламига, а там лядина, в лядине скотина - Человек (Dal 1979: II, 286). 
Here is a pitchfork, there is a barrel on top of the pitchfork, then there is a hummock on top of the barrel, then there is an open space, a little bit higher there is a plain, and (on the plain) there is a wasteland, and in the wasteland there is cattle. Answer: A human person.

As for its ominous treatment as "sacrilegious, malicious", one can refer to a word that comes from the same stem and obtains the meaning "devil, a supernatural being" ( $c f$. supernatural beings that came to the hero of the Breton folktale fozebik ha Merlin; probably, they were the wasteland inhabitants):

Лядь - все негодное и недоброе, дух пакостей, нечистый, черт (Dal 1979: II, 286).

Lyad' - that is everything that is not practical and not good, the spirit of bad tricks, the wicked, the devil.

Going back to Breton folktales, one can see that in Rolland's fozebik ha Merlin the wasteland is a liminal zone separating the human world (cultivated zone) and the Otherword. There is often a wood to the rear of the wasteland where the supernatural creatures live, the Otherworld, or the uncultivated land. In order to get access to the Otherworld and to get a permission to cross the boundary zone, the hero must first become a shepherd. Why such tendency existed, we will explain later in terms of rites of probation or initiation.

Let us come back to our discussion of the IE stem *ledh-. The linguistic evidence suggests that in Baltic and Slavonic languages it had a connotation of a boundary zone. Thus, according to Toporov:

...сам элемент *led-как бы фиксирует пограничность (во времени и в пространстве) природы и культуры, готовность и уместность первой подвергнуться действию последней - применительно к земле - от terra in-culta $\kappa$ terra culta (Toporov 1990: 264).

The element *led-in itself is connected in some respects with the notion of a border (in time and in space) of the nature and of the culture; with the readiness and the viability of the former to be influenced by the latter (i.e. in relation to the land) from the terra inculta toward the terra culta.

In the context of Breton folklore we cannot provide any examples of the wasteland becoming terra culta, meanwhile the idea of a border is very clear. 
4. Wasteland and the shepherd's initiation

A question still remains: why is this liminal zone connected with the shepherd's probation? This motif of a few Breton (and not only Breton) folktales is obviously connected with the ritual force of the shepherd whose task was not only to protect the cattle from the wild animals but also to dominate the supernatural malicious forces. The earlier Russian folklore, and, in particular, some contemporary ethnographic material from the twentieth century Northern Russia, provides some examples of magic rituals concerned with the initiation and other practices of the shepherds.

Чтобы сохранить скот, пастух может вступать в контакт с лешим, приносить лешему жертвы хлебом, яйцами, скотиной - обычно одной головой из стада, давать и исполнять обеты, например, не стричь волосы, пока продолжается сезон пастьбы, не есть ягод, не подпоясываться. Если запрет есть ягоды имеет утилитарный характер - не отвлекаться от дела, от стада, то растрепанные нестриженые волосы, пояс указывают на связи с ирреальными силами. Взамен пастух получает определенный заговор - обход, отпуск - иногда какие-либо магические предметы. У пастуха, имеющего обход, не пропадает скотина, волк, оказавшийся в стаде, ходит среди коров, не видя их, коровы хорошо кормятся и дают много молока, слушаются пастуха: например, достаточно пастуху развязать пояс, как коровы расходятся, завязать - они идут к нему (Cherepanova 1996: 166). In order to protect the cattle the shepherd can make the contact with the spirit of the forest (Russ. leshij), provide the leshij with some offerings such as bread, eggs, sometimes by killing one animal from the herd, or give and keep promises, for example, not to cut his hair off all the time while his cattle is grazing or not to eat berries and not to put any belt on. If the ban from eating berries seems to be a safety precaution - the shepherd is not supposed to draw attention to anything besides his work or his cattle; on the other hand, his long uncombed hair and the absence of a belt are connected with the Otherworld forces. In return, the shepherd gets a certain magic formula (Russ. obkhod, otpusk) or, in some cases, some magical objects. The shepherd who has got the obkhod does not experience any loss of his animals; a wolf that happened to get mixed up with the livestock may well walk through the animals without seeing them; the cows produce plenty of milk and obey the shepherd. For instance, as soon as he unties his belt - the cows go away, as soon as he ties up his belt - they come back to him. 
Let us conclude by saying that the symbolic meaning of the wasteland in Breton folktales has to do with a boundary zone which was perceived as a sacred place but at the same time as a dangerous one. The medieval practice to build a church or a chapel on the boundary zone may be a later institution, being a Christianisation of an archaic tradition to do with un-domesticated places. At such places or within the borders of terra inculta, some sacrificial actions may well had taken place, during the course of which the shepherds (ultimately connected with the Otherworld) had to accomplish some magical actions in order to win the favour of its spirits and inhabitants.

\section{References}

Afanasiev, A. N., 2008: Russian folk tales (In Russian: Народные русские сказки, М. Альфа-книга), Moscow.

Cherepanova, O. A., 1996: Mythological tales and legends of the Russian North (In Russian: Мифологические рассказы и легенды русского севера, Санкт-Петербург, изд-во С.-Петербургского Университета), St. Petersburg.

DAL, V., 1979: The Dictionary of the Live Russian Language (In Russian: Толковый словарь живого великорусского языка), Moscow.

Dundes, A., 1962: 'From Etic to Emic Units in the Structural Study of Folktales', fournal of American Folklore, 75.

Dundes, A., 1968: 'Introduction to the second edition', in: Propp, V., Morphology of the Folktale, $2^{\text {nd }}$ ed., $\mathrm{x}$-xvii.

Frazer, G., 1990: The Golden Bough, London.

Gros, J., 1989: Le trésor du breton parlé, s.l.

GVB = Favereau, F., 1993: Geriadur brezhoneg - galleg, galleg - brezhoneg,

(French : Dictionnaire du breton contemporain bilingue), Montroules.

Lévi-Strauss, C., 1964: Mythologiques: Le Cru et Le Cuit, Paris.

LÉvi-Strauss, C., 1968: Mythologiques: Du Miel aux Cendres, Paris.

Meletinski E., 1968: The Genesis of the Heroic Myth (In Russian: 'Происхождение героического эпоса. Ранние формы и архаические памятники. (Серия «Исследования по теории и истории эпоса»), Moscow: Nauka.

Meletinski, E., 1994: About Archetypes in Literature (In Russian: О литературных архетипах), Moscow.

Meletinski, E., 1998: The Poetics of the Myth, New York-London.

NekLYudov, S., 1971: 'Towards the Problem of Structural Description of the Fairytale', in: Studies in sign systems, 5 (In Russian: 'Еще раз к проблеме 
структурного описания волшебной сказки.' // Труды по знаковым системам, 5), Tartu, 63-91.

NeKlyudov, S., 2004: 'Leib, Geist und Seele in der russischen Literatur und Kultur', herausg. van Baak, J., \& S. Brouwer, Wiener Slawistischer Almanach, 54, 19-30.

Ó RiaIn, P., 1972: 'Boundary Associations in Early Irish Society', Studia Celtica, 7, 12-29.

PhilipPe, J., 1986: War roudoù Merlin e Breizh, Hor Yezh.

PRopp, V., 1968: Morphology of the Folktale, $2^{\text {nd }}$ ed., transl. L. Scott, rev. L. A. Wagner, Austin \& London: University of Texas Press.

PRopp, V., 1984: Theory and History of Folklore, University of Minnesota Press.

PRopp, V., 1989: Folklore and Reality (in Russian: Фольклор и действительность), Moscow.

Toporov, V. N., 1990: The Prussian language (In Russian: Прусский язык), Moscow.

\title{
Bretonski lanneg i ruski lyada: vidovi rubnosti u keltskim i slavenskim narodnim predajama
}

\author{
Sažetak
}

Pojam rubnosti i graničnih zona prisutan je u narodnim pričama različitih naroda, ali svaka predaja sadrži neke samosvojne osobine. Poredbeno proučavanje motiva pustopoljine kao granične zone u bretonskim i ruskim narodnim pričama pokazuje nam razliku u pogledu na obrađenu i neobrađenu zemlju i u usmenoj predaji i u mentalitetu. Različita poimanja pustopoljine u narodnim pričama povezana su s pastirskim običajima za zaštitu od zlih sila. Veza između bretonskog lanneg i ruskog lyada u značenju 'svetog mjesta, pustopoljine povezane sa zlim silama' može objasniti neke pojedinosti oko problema rubnosti u narodnim pričama.

Ključne riječi: bretonski lanneg, ruski ляда, pustopoljina, rubnost, narodne predaje

Key words: Breton lanneg, Russian ляда, wasteland, liminality, folk tales 
